\title{
CRISPR/CAS12A-BASED DIAGNOSTICS FOR COVID-19
}

\author{
Kabylbayeva A. ${ }^{1}$, Zharylgassynova K. ${ }^{1}$, Abilova A. ${ }^{1}$, Amanzholova M. ${ }^{2,3}$, \\ *Abeldenov S. ${ }^{3}$ \\ ${ }^{1}$ School of Science and Humanities, Nazarbayev University, \\ 53 Kabanbay Batyr Ave, Nur-Sultan, Kazakhstan; \\ ${ }^{2}$ L.N. Gumilyov Eurasian National University, \\ 13, Kazhymukan street, Nur-Sultan, Kazakhstan; \\ ${ }^{3}$ National Center for Biotechnology, \\ 13/5, Korgalzhyn road, Nur-Sultan, 010000, Kazakhstan. \\ *abeldenov@biocenter.kz.
}

\begin{abstract}
Access to fast and reliable methods for the detection of nucleic acids is critical in many different fields. Early identification of pathogens based on their genetic information associated with various diseases makes early diagnosis and treatment possible.

The situation with the COVID-19 pandemic has shown that right now there is an urgent need to find enzymes for new diagnostic methods based on modern fundamental knowledge. Methods that allow covering a wider range of applications will be cheaper and do not require specialized premises, qualified personnel and will be simple to implement.

One of these enzymes is the recently discovered endonuclease of the CRISPR/Cas systems Cas12a. In this review, we provide a description of the Cas12a enzyme and its use in the COVID-19 diagnostics.
\end{abstract}

Key words: CRISPR-Cas12a, COVID-19, diagnostics, SARS-CoV-2, RT-RPA, RT-LAMP

\section{INTRODUCTION}

Severe acute respiratory syndrome coronavirus 2 (SARS-CoV-2) caused the worldwide pandemic in 2019. This name was given to the virus due to its similarity to SARS-CoV. Betacoronavirus is the root cause of pandemic, which is a member of Coronaviridae family, Coronavirinae subfamily. Alphacoronavirus, gammacoronavirus and deltacoronavirus are members of this subfamily, occurring as a result of mutations in the replication process that produce more virulent types of virus. Alpha variant was first documented in the UK in September, 2020, beta variant was found in South Africa in May, 2020. Gamma variant was reported in Brazil in November, 2020, delta was identified in India in October, 2020. They are enveloped positive-stranded ribonucleic, and have the largest genome size accounting for $\sim 27$ to $\sim 32$ kilobase pairs.

The first case of acute respiratory syndrome caused by SARS-CoV-2 was reported in Wuhan, China in 2019. People above 60 years and people with underlying comorbidities such as lung, heart disease, pressure and diabetes are vulnerable to develop this disease. On average, the symptoms start to express on 5-6th days after being exposed to COVID-19. The most common symptoms of this disease are fever, dry cough, loss of smell and taste. Some people may not have any symptoms at all and asymptomatically carry it, while others can have difficulties with breathing and chest pain, to incur such severe cases mechanical ventilators may be needed. On November 
19th, 2021, based on the WHO statistics, 255.324.963 positive cases and 5.127.696 deaths were reported.

There are at least 13 vaccine types that have been approved by WHO. The vaccination began in December, 2020. Approved vaccines are considered effective taking into account evolving nature of viruses and considered as an appropriate measure to reduce the spread of virus among individuals and as a solution against evolving virulent variants. Statistics on November 17th, 2021 shows that 7.370.902.499 vaccine doses were uptaken.

COVID-19 diagnostics. COVID-19 testing starts with collecting samples. A nasopharyngeal swab is used to detect the virus. And there are also new approaches to collecting samples, including saliva and less invasive nasal swabs. Diagnostics of COVID-19 includes detection of nucleic acids, antibodies and proteins, antigen detection methods are also available, molecular test based on GeneXpert (Cepheid) and Truenat (Molbio) cartridge, as well as automated high-throughput molecular analyzes Roche Cobas, Abbott SARS CoV-2, Genmark ePlex analysis, etc. The best show a limit of detection (LOD) of $\sim 100$ copies of viral RNA per milliliter of transport medium.

Diagnostic testing for COVID-19 aims to identify patients infected with SARSCoV-2. Therefore, highly sensitive methods are needed, such as PCR, that do not allow false negative and false positive results. RT-PCR or reverse transcription polymerase chain reaction is the most common method for diagnosing COVID-19 due to its high sensitivity, it is possible to identify an infected person at the early stages of spread. RTPCR is an expensive test and requires a well-equipped molecular laboratory with trained personnel. Many countries have an acute shortage of diagnostic kits. These tests are usually performed by a centralized laboratory diagnostic system with specialized equipment. The results of such tests can be provided within 12-48 hours. However, depending on the level of public health development of the countries, the availability of the necessary equipment, distance and other related barriers, processing time can exceed 5-10 days. Therefore, such results, which were obtained a few days after sampling, cannot affect the effective prevention of transmission of the pathogen, since by that time the individual will no longer have shed the virus. Therefore, tests are needed that can give a result in the shortest possible time. These tests do not require tools or skilled operators, allowing wider and more widespread testing of the population [1].

Antigen testing is widely used as a faster and more convenient alternative to PCR, but it is less sensitive and should only be used for early diagnosis after symptoms appear. The detected antigens are expressed only if the virus is actively multiplying; therefore tests can be used to detect acute or early infection.

The contagiousness of coronavirus infection is achieved during or before the onset of clinical symptoms. Asymptomatic and presymptomatic cases are the main factors in the spread of the virus. Thus, prevalence of infection with presymptomatic viral load reduces the effectiveness of preventive measures such as isolation, contact tracing and hygiene or the use of masks [2]. Therefore, it is necessary to identify carriers of the virus even before the manifestation of clinical symptoms. This can be achieved through quick tests. Despite the high sensitivity of the gold method for PCR diagnostics, an important feature of large-scale screening of the population is that centralized laboratory diagnostics does not achieve herd immunity as efficiently as compared to rapid and affordable tests [3], [4].

Like home pregnancy tests, screening tests should be easy to obtain and administer, fast and cheap. The frequency and number of tests should be prioritized before achieving high analytical sensitivity. The loss of sensitivity of rapid tests within reasonable limits can be compensated for by the frequency of testing and the wider distribution of tests. The key question is not the efficiency of how the molecules can be 
detected in a single sample, but how effectively infections can be detected in a population by reusing a given test as part of an overall testing strategy - the sensitivity of the testing regimen [5]. In summary, new diagnostic methods must combine the high sensitivity of PCR and the availability and speed of tests such as ICA antigen tests. This method can be based on the use of enzymes of CRISPR/Cas systems. In this review, we present a description of the Cas12a enzyme and its application in the COVID-19 diagnostics.

CRISPR/Cas. A CRISPR (clustered regularly interspaced short palindromic repeats) is a genomic locus in bacteria. It was first found in Escherichia coli; it contained repeated DNA sequences and spacer sequences located between those repeated ones. Even though it was found in bacteria, it was identified only in $40 \%$ of bacteria species and in $90 \%$ of archaea. In the beginning, the role of the spacer sequence was not understandable. Later, it was identified that spacer sequences were identical to the genomes of bacteriophages. After that, the CRISPR system is considered as a molecular immunity mechanism against foreign invading mobile genetic elements (MGEs) such as bacteriophages. To protect bacteria and archaea from invading the phage, their genome fragments must be in the CRISPR locus. That is done by the following steps. First, a foreign genome is cleaved into fragments, which is also known as protospacers. They are then inserted into the CRISPR loci and become new spacers. Later, when this region is transcribed, its transcript is called CRISPR-derived RNA (crRNA). The crRNA contains a single spacer and two repeated sequences on both sides of the spacer region. Finally, crRNA associates with Cas proteins which includes nuclease complexes. Those Cas nucleases cleave the invading genome and neutralize them. The system of CRISPR-Cas is now widely used in genome editing, regulating transcriptions, gene therapy, and detecting nucleic acids.

The rapid emergence of CRISPR/Cas technology for genome manipulation has revolutionized the life sciences. Almost all archaea and many bacteria possess adaptive immunity using a diverse set of CRISPR/Cas systems. CRISPR/Cas immunity includes three major sequential steps: adaptation, expression / maturation and interference, each step requires specific Cas proteins encoded by cas genes near CRISPR loci, along with other accessory proteins. This adaptive immune system helps bacteria and archaea defend against invasion of foreign nucleic acids.

The diverse spectrum of CRISPR/Cas systems can be divided into 2 classes, 6 types and 33 subtypes. Class 1 systems (types I, III, and IV) use a complex of several Cas proteins, while class 2 systems (types II, V, and VI) use a single enzyme such as Cas9. Class 1 CRISPR/Cas systems are most often found in bacteria and archaea and account for $\sim 90 \%$ of all identified CRISPR/Cas loci. Class 2 CRISPR/Cas systems, accounting for the remaining $\sim 10 \%$, exist mainly exclusively in bacteria. The most widely characterized CRISPR/Cas system is subtype II-A type II found in Streptococcus pyogenes, which uses the Cas9 protein.

Cas9. One of the most widely used types of CRISPR-Cas is type II, Cas9 nuclease. Cas9 cleaves the foreign DNA by selecting a sequence called protospacer adjacent motif (PAM). This sequence is as follows: 5'-NGG-3', there might be any nucleotide instead of $\mathrm{N}$. The protospacer sequence must be located next to PAM. There are two nuclease domains in Cas9: HNH domain, which cuts the DNA complementary to crRNA; RuvC domain, which cuts the non-complementary DNA strand. The cleavage of the target genome occurs only if a region complementary to crRNA is located next to PAM. It helps to avoid cleavage of CRISPR loci or own DNA as they lack PAM sequence. In 2020, Jennifer Doudna and Emmanuelle Charpentier, who worked with CRISPR-Cas9, won the Nobel Prize in Chemistry for investigating CRISPR-Cas based gene-editing systems. 
Cas13. In type VI, a member of the CRISPR-Cas system is Cas13. The main difference between Cas 13 from Cas 9 is that its target is single-stranded RNA, not DNA. The size of Cas13 varies from 954 to 1389 amino acids, depending on its subtypes. There are four subtypes of Cas13: Cas13a, Cas13b, Cas13c, and Cas13d. The most widely used one is Cas13a. We will look closer at Cas13a. Cas13a makes a complex with the crRNA when it recognizes the target sequence and becomes activated; then, Cas13a cleaves the ssRNA. To cleave the RNA Cas13a requires a protospacer flanking site (PFS), which has the same role as the PAM sequence in the CRISPR-Cas9 system. The CRISPR-Cas13a system is widely used in nucleic acid detection. Its application method in diagnosis is known as SHERLOCK, which stands for Specific HighSensitivity Enzymatic Reporter Unlocking. It is called so due to its ultrasensitive and specific identification of DNA or RNA. The SHERLOCK is used to detect Zika virus and dengue virus in very high sensitivity.

Cas 12a. The CRISPR-Cas type V system is further subdivided into four subtypes, such as V-A, V-B, V-C, V-U. This paper reviews the V-A subtype, which applies a protein Cas12a (Cpf1). Cas 12a is a protein containing approximately 1300 amino acids. It targets a double-stranded DNA (dsDNA), which contains a short T-rich PAM sequence on the 5' end of the non-target strand. Cas $12 \mathrm{a}$ is a highly specific programmable nuclease with a high efficiency comparable to Cas9. There are several distinctive features between Cas9 and Cas12a. It was shown that Cas12a requires only one processed crRNA, unlike Cas9, which makes it a unique effector protein with endoribonuclease and endonuclease activities. Cas12a requires a thymine-rich PAM region at the 5 'end, in contrast to a guanine-rich PAM region at the 3 ' end of the target DNA for Cas9 systems. Cas12a generates a sticky double-stranded break, while Cas9 creates blunt ends within the PAM-proximal target site. Cas12a and Cas9 have functional similarities, despite the fact that enzymes have evolutionarily independent developmental pathways. Enzymes have comparable molecular weights (1368 amino acids for SpCas9; 1307 for FnCas12a). Both are multi-domain effector proteins. Cas9 requires two RNA molecules: tracrRNA and crRNA, while Cas12a requires only one RNA molecule - crRNA.

The nuclease domain that is present both in Cas9 and Cas12a is Ruv-C like nuclease domain, but the endonuclease domain was not identified in Cas12a. It also employs a bilobed arrangement that is created by REC and Nuc lobes. The REC lobe is composed of REC1 and REC2 domains, while the Nuc lobe is composed of the RuvC, PAM-interacting, WED domains, and the bridge helix (BH). The RNase site for crRNA is located in the WED-III, while the DNase site is situated in between the RuvC and the Nuc domains. The repeat sequence made up of 19/20 nt creates a stem-loop arrangement due to the complementary base pairing.

The detection of the PAM region is a significant part of the CRISPR-Cas system. The PAM region is TTTV, where V is any nucleotide except for T. Cpf1 uses the WED II-III, REC1 and PAM-interacting domains to ensure the accurate recognition of the PAM sequence. This, in turn, is followed by the introduction of the conserved looplysine helix-loop (LKL) region in the PI domain that comprises three conserved lysines, into the PAM duplex. The dsDNA starts uncoiling which is assisted by the angle relative to the dsDNA at which the LKL was introduced. This process forces the crRNA, the target strand, and the PAM-associated strand to be hybridized, while the uncoupled DNA strand, non-target strand (NTS) will be associated with the DNase site.

Because of the features described above, Cas12a may be even the best alternative genome editing tool in some situations. It has been suggested that Cas12a is highly specific in human cells with low rates of deviation from the target (nonspecific activity in non-target regions of the genome (off-target sites)) [6], [7]. Recently, several high- 
resolution Cas12a structures have been obtained and features of the working mechanism of the enzyme have been presented [8], [9], [10].

Collateral cleavage activity. However, in addition to its therapeutic potential, it has recently been discovered that CRISPR technology can be used in the diagnostics [11]. In addition to the highly specific cleavage of dsDNA, Cas12a also exhibits a nonspecific ssDNA degradation activity. This activity is manifested by almost all Cas $12 \mathrm{a}$ orthologues and cleaves any available ssDNA molecule [11]. It is known that Cas12a, Cas13a, and Cas14 endonucleases possess collateral activity, which was used in the detection of nucleic acids [11], [12]. These platforms provide attomolar sensitivity and specificity for detecting a variety of nucleic acid targets.

Recent publications show that research efforts are focused on expanding the number of known CRISPR/Cas subtypes to identify nucleases with new properties. The functional diversity of nucleases within each subtype remains poorly understood.

Cas12a nucleases from Acidaminococcus sp. (AsCas12a), bacteria Lachnospiraceae ND2006 (LbCas12a) and Francisella novicida (FnCas12a) have been characterized. The Cas12a enzyme has a DNA-activated DNase activity, which, upon formation of the Cas12a/crRNA/target DNA ternary complex, leads to the cleavage of nonspecific single-stranded DNA molecules. Also, nucleases were found to be able to process and use each other's guide RNA to target DNA, although they differed in DNA cleavage activity and PAM preference, regardless of their phylogenetic relationship [13]. Thus, uncharacterized enzymes of the Cas12a family most likely have different profiles of PAM regions between closely related orthologs, which leaves fundamental questions about the nature of the evolution of certain sequences in front of protospacers.

Pre-amplification methods. In view of the fact that in certain cases, especially at the onset of the disease, the viral load in the body is too low, carrying out only one stage of reverse transcription, followed by analysis of Cas12a, is insufficient to detect the pathogen. In this case, preliminary amplification is carried out using various isothermal methods. Today, there are several methods for preliminary amplification of target genes for the diagnosis of COVID-19.

$\boldsymbol{R T}$-LAMP. RT-LAMP is used to convert viral RNA into complementary DNA (cDNA). Once the cDNA has formed, it serves as a template for amplification at constant temperature. Thus, when using RT-LAMP, there is no need to use an expensive thermal cycler. After the formation of cDNA, the product serves as a template for the formation of DNA loop structures due to the peculiarity of the primer design. RT-LAMP does not require expensive reagents and a sufficient number of different protocols are available to optimize the reaction parameters, which makes this method available to many laboratories for the implementation of POC diagnostics.

$\boldsymbol{R T} \boldsymbol{T} \boldsymbol{R P A}$. The next method for preliminary amplification of target sequences is recombinase polymerase amplification. The method is highly sensitive and is carried out at a constant temperature of $37-42{ }^{\circ} \mathrm{C}$. The principle of the method is to bind opposite oligonucleotide primers to template DNA and extend them using DNA polymerase without template denaturation. The recombinase-primer complex moves along the DNA to search for a complementary site. The primer-mixed DNA strand is stabilized by proteins that bind single-stranded DNA. Then DNA polymerase, using the 3 'end of the primer, extends the oligonucleotide using dNTP.

Detection of SARS-CoV-2 using CRISPR/Cas12-based assays. The coronavirus pandemic has rapidly evolved into the development of fast and affordable diagnostics. In a relatively short period of time, researchers published various diagnostic options for the causative agent SARS-CoV-2 using the Cas12a enzyme (Table 1).

Table 1. Cas12a-based detection of SARS-CoV-2 


\begin{tabular}{|c|c|c|c|c|c|c|}
\hline $\begin{array}{l}\text { Method } \\
\text { abbreviation }\end{array}$ & Amplification & Target & Time & $\begin{array}{l}\text { Limit of } \\
\text { detection }\end{array}$ & $\begin{array}{l}\text { Readout } \\
\text { method }\end{array}$ & Reference \\
\hline iSCAN & RT-LAMP & $\mathrm{N}$ and $\mathrm{E}$ genes & $\begin{array}{l}\text { less } \\
\text { than } \\
1 \mathrm{~h}\end{array}$ & $\begin{array}{l}10 \text { RNA } \\
\text { copies per } \\
\text { reaction }\end{array}$ & $\begin{array}{l}\text { fluorescence } \\
\text { lateral flow }\end{array}$ & [17] \\
\hline DETECTR & RT-LAMP & $\begin{array}{l}\text { E (envelope) } \\
\text { and } \mathrm{N} \\
\text { (nucleoprotein) } \\
\text { genes }\end{array}$ & $\begin{array}{l}30- \\
40 \\
\min \end{array}$ & $\begin{array}{l}10 \text { copies } \\
\text { per } \mu l \\
\text { reaction }\end{array}$ & $\begin{array}{l}\text { fluorescence } \\
\text { lateral flow }\end{array}$ & [18] \\
\hline DETECTR & RT-LAMP & $\mathrm{E}$ and $\mathrm{N}$ genes & $\begin{array}{l}\sim 30 \\
\min \end{array}$ & $\begin{array}{l}10 \\
\text { copies } / \mu \mathrm{L} \\
\text { reaction }\end{array}$ & lateral flow & [19] \\
\hline - & RT-LAMP & $\begin{array}{l}\text { ORF gene, } \mathrm{N} \\
\text { gene and } \mathrm{E} \\
\text { gene }\end{array}$ & $\begin{array}{l}\text { less } \\
\text { than } \\
1 \mathrm{~h}\end{array}$ & $\begin{array}{l}20 \text { copies } \\
\text { RNA per } \\
\text { reaction }\end{array}$ & fluorescence & [20] \\
\hline AIOD-CRISPR & RPA & $\mathrm{N}$ gene & $\begin{array}{l}20 \\
\min \end{array}$ & $\begin{array}{l}5 \text { RNA } \\
\text { targets per } \\
\text { reaction }\end{array}$ & fluorescence & {$[21]$} \\
\hline CASdetec & RAA & RdRp & $\begin{array}{l}10- \\
30 \\
\min \end{array}$ & $\begin{array}{l}5 \times 10^{3} \\
\text { copies/mL } \\
\text { of SARS- } \\
\text { CoV-2 } \\
\text { RNA } \\
\text { samples }\end{array}$ & fluorescence & [22] \\
\hline CRISPR-FDS & RT-PCR & $\begin{array}{l}\text { ORF1ab and N } \\
\text { genes }\end{array}$ & $\begin{array}{l}\sim 50 \\
\min \end{array}$ & $\begin{array}{l}\geq 2 \text { copies } \\
\text { of the } \\
\text { target } \\
\text { RNA } \\
\text { sequence }\end{array}$ & fluorescence & [23] \\
\hline ITP-CRISPR & RT-LAMP & $\mathrm{E}$ and $\mathrm{N}$ genes & $\begin{array}{l}30- \\
40 \\
\min \end{array}$ & $\begin{array}{l}10 \text { copies } \\
\text { per } \mu \mathrm{L} \text { of } \\
\text { reaction }\end{array}$ & fluorescence & [24] \\
\hline $\begin{array}{l}\text { CRISPR/Cas12a- } \\
\text { NER }\end{array}$ & RT-RAA & $\begin{array}{l}\text { orf1a, orf1b, } \mathrm{N} \\
\text { and } \mathrm{E} \text { genes }\end{array}$ & $\begin{array}{l}45 \\
\min \end{array}$ & $\begin{array}{l}10 \text { copies } \\
\text { of the } \\
\text { virus gene }\end{array}$ & fluorescence & {$[25]$} \\
\hline- & RT-RPA & $\begin{array}{l}\text { ORF1ab and } \mathrm{N} \\
\text { genes }\end{array}$ & $\begin{array}{l}50 \\
\min \end{array}$ & $\begin{array}{l}1-10 \\
\text { copies per } \\
\text { reaction }\end{array}$ & $\begin{array}{l}\text { fluorescence } \\
\text { lateral flow }\end{array}$ & [26] \\
\hline Lyo-CRISPR & RT-LAMP & $\mathrm{N}$ gene & $1 \mathrm{~h}$ & $\begin{array}{l}7.5 \\
\text { copies/ } \mu \mathrm{L}\end{array}$ & fluorescence & [27] \\
\hline dWS-CRISPR & RT-DAMP & $\mathrm{N}$ gene & $\begin{array}{l}90 \\
\min \end{array}$ & 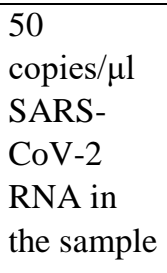 & fluorescence & {$[28]$} \\
\hline - & RT-LAMP & $\mathrm{N}$ gene & 40 & 16 & fluorescence & [29] \\
\hline
\end{tabular}




\begin{tabular}{|c|c|c|c|c|c|c|}
\hline & & & $\min$ & copies $/ \mu \mathrm{L}$ & colorimetric & \\
\hline PGMs-CRISPR & RT-RAA & $\mathrm{N}$ gene & $\begin{array}{l}60- \\
90 \\
\min \end{array}$ & $\begin{array}{l}10 \\
\text { copies/ } \mu \mathrm{L}\end{array}$ & biosensor & [30] \\
\hline symRNA-Cas12a & RT-RPA & $\mathrm{E}$ and $\mathrm{S}$ genes & $\begin{array}{l}45 \\
\min \end{array}$ & $\begin{array}{l}10 \text { copies } \\
\text { of } \\
\text { synthetic } \\
\text { mutant } \\
\text { RNA }\end{array}$ & fluorescence & [31] \\
\hline CRISPR-FDS & RT-RPA & ORF1ab gene & $\begin{array}{l}15 \\
\min \end{array}$ & $\begin{array}{l}0.38 \\
\text { copies/ } \mu \mathrm{L}\end{array}$ & fluorescence & [32] \\
\hline VaNGuard & RT-LAMP & S gene & $\begin{array}{l}45 \\
\min \end{array}$ & $\begin{array}{l}20 \text { copies } \\
\text { per } \\
\text { reaction }\end{array}$ & $\begin{array}{l}\text { fluorescence } \\
\text { lateral flow }\end{array}$ & [33] \\
\hline deCOViD & RT-RPA & $\mathrm{N}$ gene & $\begin{array}{l}30 \\
\min \end{array}$ & $\begin{array}{l}1 \text { genome } \\
\text { equivalent } \\
(\mathrm{GE}) \mu \mathrm{L}^{-1} \\
\text { of SARS- } \\
\text { CoV-2 } \\
\text { RNA }\end{array}$ & fluorescence & [34] \\
\hline- & RT-LAMP & $\mathrm{E}$ and $\mathrm{N}$ genes & $\begin{array}{l}35 \\
\min \end{array}$ & $\begin{array}{l}35 \text { copies } \\
\text { per } \mu \mathrm{L}\end{array}$ & lateral flow & [35] \\
\hline CASCADE & $\begin{array}{l}\text { amplifiation- } \\
\text { free }\end{array}$ & ORF1ab gene & $\begin{array}{l}71 \\
\min \end{array}$ & $\begin{array}{l}50 \\
\text { copies } / \mu \mathrm{L}\end{array}$ & fluorescence & [36] \\
\hline opvCRISPR & RT-LAMP & S gene & $\begin{array}{l}45 \\
\min \end{array}$ & 5 copies & fluorescence & [37] \\
\hline \multirow[t]{2}{*}{ MCCD } & RT-MCDA & $\begin{array}{l}\text { ORF1ab and } \mathrm{N} \\
\text { genes }\end{array}$ & $1 \mathrm{~h}$ & $\begin{array}{l}7 \text { copies } \\
\text { per } \\
\text { reaction }\end{array}$ & lateral flow & [38] \\
\hline & RT-PCR & $\mathrm{N}$ gene & $\begin{array}{l}\sim 90 \\
\min \end{array}$ & 1 сору $/ \mu \mathrm{L}$ & biosensor & [16] \\
\hline $\begin{array}{l}\text { CRISPR- } \\
\text { ENHANCE }\end{array}$ & RT-LAMP & $\mathrm{N}$ gene & $\begin{array}{l}40 \\
\min \end{array}$ & $\begin{array}{l}3-300 \\
\text { copies }\end{array}$ & $\begin{array}{l}\text { fluorescence } \\
\text { lateral flow }\end{array}$ & [39] \\
\hline- & RT-LAMP & $\mathrm{E}$ and $\mathrm{N}$ genes & $\begin{array}{l}40 \\
\min \end{array}$ & $\begin{array}{l}\text { E gene - } \\
45 \\
\text { copies/ } \mu \mathrm{L} \\
\mathrm{N} \text { gene - } \\
30 \\
\text { copies } / \mu \mathrm{L}\end{array}$ & fluorescence & [40] \\
\hline CLAP & RT-LAMP & $\mathrm{N}$ gene & $\begin{array}{l}40 \\
\min \end{array}$ & $\begin{array}{l}4 \\
\text { copies } / \mu \mathrm{L}\end{array}$ & colorimetry & {$[41]$} \\
\hline- & RT-LAMP & $\mathrm{E}$ and $\mathrm{N}$ genes & $\begin{array}{l}45 \\
\min \end{array}$ & $\begin{array}{l}225 \text { copies } \\
\text { of the } \mathrm{N} \\
\text { gene }\end{array}$ & colorimetry & [42] \\
\hline
\end{tabular}




\begin{tabular}{|l|l|l|l|l|l|l|}
\hline & & & $\begin{array}{l}300 \text { copies } \\
\text { of the E } \\
\text { gene }\end{array}$ & & \\
\hline S-CRISPR & $\begin{array}{l}\text { reverse } \\
\text { transcription }\end{array}$ & N gene & $\begin{array}{l}30- \\
40 \\
\text { min }\end{array}$ & $2 \mathrm{fM}$ & biosensor & [43] \\
\hline
\end{tabular}

As a preliminary amplification, in most cases such methods of isothermal reactions as RT-LAMP and RPA were proposed. However, isothermal amplification methods are not specific enough and cannot always determine the polymorphism of the target sequence, in contrast to Cas12a [14], [15]. That is why these methods are complemented by the Cas12a assay. Almost all methods were able to identify the pathogen within 30-60 minutes, which, of course, compared to qPCR, makes this method relatively fast, less laborious and comparable in sensitivity and specificity. An important advantage is also the ability to assess the result of the reaction using available methods, either by fluorescence, or using test strips of immunochromatographic analysis. And also, papers were published where a smartphone can be used as a detector [16]. The general diagnostic scheme is shown in Figure 1.

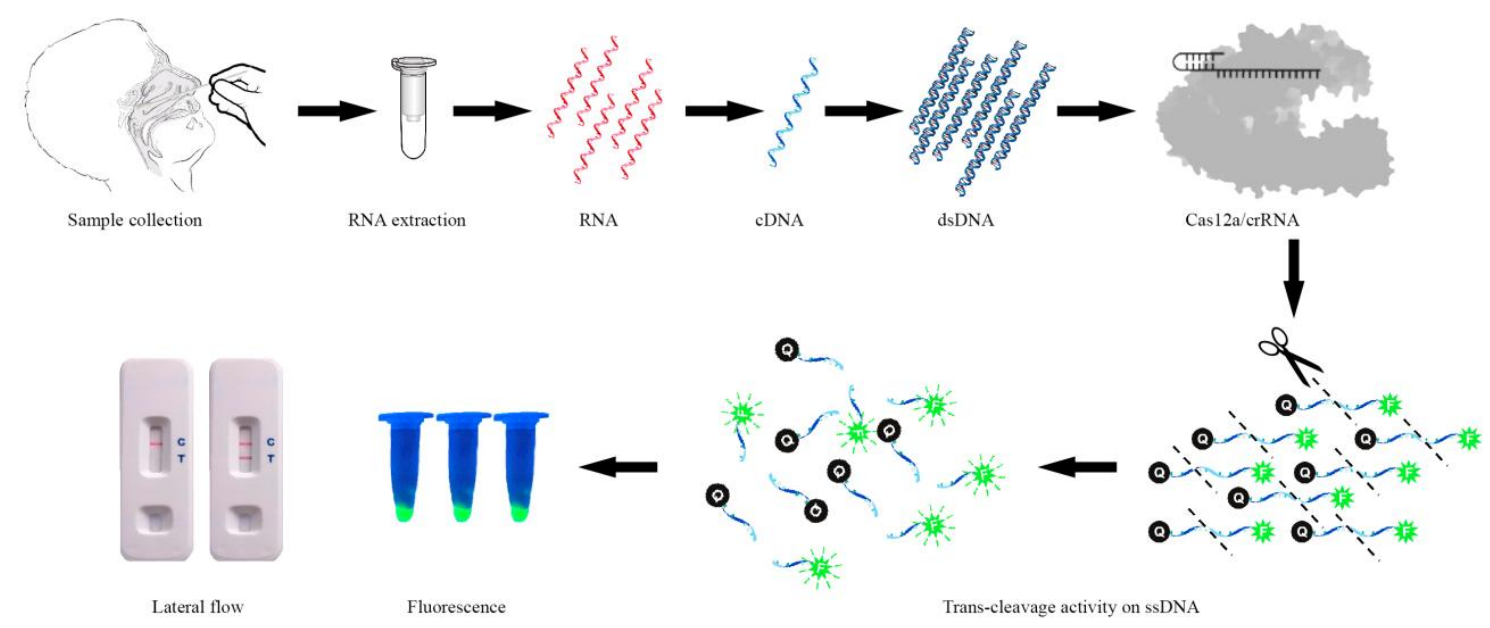

Fig. 1. SARS CoV-2 detection using Cas $12 \mathrm{a}$

\section{CONCLUSION}

There is a need for nucleic acid diagnostic tools that combine the sensitivity, specificity, and flexibility of conventional genomic diagnostics with the simplicity, cost-effectiveness and speed of isothermal amplification methods. This diagnostic tool is ideal for point-of-care (POC) testing.

The COVID-19 pandemic has been a powerful impetus for the development of fast and affordable diagnostic methods around the world. In the shortest possible time, diagnostic methods such as SHERLOCK, DETECTR, BinaxNOW COVID-19 Ag, SalivaDirect, etc. were presented. Therefore, there is definitely a great urgency in the search and functional characterization of new nucleic acid hydrolysis enzymes, for the development of new diagnostic methods - fast, affordable, convenient to use and do not require medical personnel and expensive equipment. 
In this review, we described a new enzyme Cas12a, its distinctive features, and its potential for use in diagnostics, especially in the light of recent events, in the diagnosis of coronavirus infection. It is known that the CRISPR/Cas12a system nonspecifically cleaves single-stranded DNA after binding to target DNA sequences. This usually required that the target DNA strands contain a sequence of a strictly defined motif adjacent to the protospacer (PAM region) TTTN. Just recently, it was found that Cas 12a can also recognize another PAM region sequence - UUUN, which leads to the activation of its effect of collateral cleavage of ssDNA [44]. It was also shown that using Cas12a in combination with the LAMP reaction, it was possible to realize direct visualization of DNA detection at the level of just one copy.

Until recently, components of the CRISPR/Cas systems were found exclusively in archaea and bacteria, however, in February 2020, a paper was published, which reported the discovery of hundreds of new genomes of bacteriophages from various ecosystems. Sequencing of these genomes made it possible to identify various and previously undescribed CRISPR/Cas systems [45]. In particular, a new representative of Cas enzymes was discovered and described - Cas $12 \mathrm{j}(\operatorname{Cas} \Phi)$. Cas $\Phi$ has a molecular weight of half $(\sim 70-\mathrm{kDa})$ than Cas9 and Cas12a genome editing enzymes and expands the genome editing toolbox [46]. As can be seen, the area of study has not yet defined horizons and, most likely, publications about new fundamental data will appear soon.

Thus, despite numerous recent advances in the study of Cas $12 \mathrm{a}$, there remains vast potential for the unexplored potential of Cas12a in terms of therapy and diagnostics.

By switching to cheaper tests that can produce results in less than an hour, potentially detecting people, including asymptomatic people [47], it will be possible to contain the epidemic before it spreads. Thus, new types of diagnostics will play a direct role in the epidemiology of the spread of infections.

This is very important for regions remote from the centralized diagnostics system, where the time for transporting samples can take several days. This is especially true for Kazakhstan, which has a huge area of territory and many remote settlements, which, in turn, requires complex logistics for timely diagnosis of the population. Therefore, the existing diagnostic system is nothing more than a statement of the diagnosis because the patient will continue to spread the infection while waiting for the results. It should be added that the number of qualified personnel and expensive equipment is concentrated, as a rule, in large cities. Therefore, the development of new diagnostic methods is relevant, both from the side of economic interest (reaction time and cheapness), and from the side of society (lack of expensive equipment). To combat the COVID-19 pandemic, urgently new diagnostic methods that meet the ASSURED criteria (Affordable, Sensitive, Specific, User-friendly, Rapid and Robust, Equipment-free, and Deliverable to end-users) for POC diagnostics (point-of-care) [48, 49, 50]. The development of new methods for COVID-19 diagnostics based on Cas12a is fundamentally different from the currently generally accepted tests, therefore, the criteria for evaluating new methods should be revised for their further registration and wider coverage of the population.

\section{Acknowledgements}

This work was supported by the Science Committee of the Ministry of Education and Science of the Republic of Kazakhstan (Grant No. AP09259771).

\section{REFERENCES}


1. Mina M. J., Andersen K. G. COVID-19 testing: One size does not fit all. Science, 2021, vol. 371, no. 6525, pp. 126-127.

2. He X., Lau E. H. Y., Wu P., Deng X., Wang J., Hao X., Lau Y. C., Wong J. Y., Guan Y., Tan X., Mo X., Chen Y., Liao B., Chen W., Hu F., Zhang Q., Zhong M., Wu Y., Zhao L., Zhang F., Cowling B. J., Li F., Leung G. M. Temporal dynamics in viral shedding and transmissibility of COVID-19. Nat Med., 2020, vol. 26, no. 5, pp. 672675 .

3. Larremore D. B., Wilder B., Lester E., Shehata S., Burke J. M., Hay J. A., Tambe M., Mina M. J., Parker R. Test sensitivity is secondary to frequency and turnaround time for COVID-19 screening. Sci Adv., 2021, vol. 7, no. 1 :eabd5393. doi: 10.1126/sciadv.abd5393

4. Pavelka M., Van-Zandvoort K., Abbott S., Sherratt K., Majdan M., Jarčuška P., Krajčí M., Flasche S., Funk S. The impact of population-wide rapid antigen testing on SARS-CoV-2 prevalence in Slovakia. Science, 2021, vol. 372, no. 6542, pp. 635-641.

5. Mina M. J., Parker R., Larremore D. B. Rethinking Covid-19 Test Sensitivity A Strategy for Containment. N Engl J Med., 2020, vol. 383, no. 22, pp. 120.

6. Kleinstiver B. P., Tsai S. Q., Prew M. S., Nguyen N. T., Welch M. M., Lopez J. M., McCaw Z. R., Aryee M. J., Joung J. K. Genome-wide specificities of CRISPR-Cas Cpf1 nucleases in human cells. Nat Biotechnol., 2016, vol. 34, no. 8, pp. 869-74.

7. Kim D., Kim J., Hur J. K., Been K. W., Yoon S. H., Kim J. S. Genome-wide analysis reveals specificities of Cpf1 endonucleases in human cells. Nat Biotechnol., 2016, vol. 34, no.8, pp. 863-8.

8. Stella S., Alcón P., Montoya G. Structure of the Cpfl endonuclease R-loop complex after target DNA cleavage. Nature, 2017, vol. 546, no. 7659, pp. 559-563.

9. Dong D., Ren K., Qiu X., Zheng J., Guo M., Guan X., Liu H., Li N., Zhang B., Yang D., Ma C., Wang S., Wu D., Ma Y., Fan S., Wang J., Gao N., Huang Z. The crystal structure of Cpf1 in complex with CRISPR RNA. Nature, 2016, vol. 532, no. 7600, pp. 522-6.

10. Yamano T., Nishimasu H., Zetsche B., Hirano H., Slaymaker I. M., Li Y., Fedorova I., Nakane T., Makarova K. S., Koonin E. V., Ishitani R., Zhang F., Nureki O. Crystal Structure of Cpf1 in Complex with Guide RNA and Target DNA. Cell, 2016, vol. 165 , no. 4, pp. 949-62.

11. Chen J. S., Ma E., Harrington L. B., Da Costa M., Tian X., Palefsky J. M., Doudna J. A. CRISPR-Cas12a target binding unleashes indiscriminate single-stranded DNase activity. Science, 2018, vol. 360, no. 6387, pp. 436-439.

12. Harrington L. B., Burstein D., Chen J. S., Paez-Espino D., Ma E., Witte I. P., Cofsky J. C., Kyrpides N. C., Banfield J. F., Doudna J. A. Programmed DNA destruction by miniature CRISPR-Cas14 enzymes. Science, 2018, vol. 362, no. 6416, pp. 839-842.

13. Jacobsen T., Ttofali F., Liao C., Manchalu S., Gray B. N., Beisel C. L. Characterization of Cas12a nucleases reveals diverse PAM profiles between closelyrelated orthologs. Nucleic Acids Res., 2020, vol. 48, no. 10, pp. 5624-5638.

14. Xiao G., Liu S., Liu H., He X., Zhang S., Liang Z., Guo H., Ou M., Zhou L., Liu L., Zhang T., Zhang G. CRISPR/Cas12a-based biosensing platform for precise and efficient screening of CRISPR/Cas9-induced biallelic mutants. Talanta, 2020, vol. 210, pp. 120613.

15. Chen Y., Mei Y., Jiang X. Universal and high-fidelity DNA single nucleotide polymorphism detection based on a CRISPR/Cas12a biochip. Chem Sci., 2021, vol. 12 , no. 12 , pp. 4455-4462.

16. Ma L., Yin L., Li X., Chen S., Peng L., Liu G., Ye S., Zhang W., Man S. A smartphone-based visual biosensor for CRISPR-Cas powered SARS-CoV-2 diagnostics. Biosens Bioelectron., 2022, vol. 195, pp. 113646. 
17. Ali Z., Aman R., Mahas A., Rao G. S., Tehseen M., Marsic T., Salunke R., Subudhi A. K., Hala S. M., Hamdan S. M., Pain A., Alofi F. S., Alsomali A., Hashem A. M., Khogeer A., Almontashiri N. A. M., Abedalthagafi M., Hassan N., Mahfouz M. M. iSCAN: An RT-LAMP-coupled CRISPR-Cas12 module for rapid, sensitive detection of SARS-CoV-2. Virus Res., 2020, vol. 288, pp. 198129.

18. Broughton J. P., Deng X., Yu G., Fasching C. L., Servellita V., Singh J., Miao X., Streithorst J. A., Granados A., Sotomayor-Gonzalez A., Zorn K., Gopez A., Hsu E., Gu W., Miller S., Pan C. Y., Guevara H., Wadford D. A., Chen J. S., Chiu C. Y. CRISPR-Cas12-based detection of SARS-CoV-2. Nat Biotechnol., 2020, vol. 38, no. 7, pp. 870-874.

19. Broughton J. P., Deng X., Yu G., Fasching C. L., Singh J., Streithorst J., Granados A., Sotomayor-Gonzalez A., Zorn K., Gopez A., Hsu E., Gu W., Miller S., Pan C. Y., Guevara H., Wadford D. A., Chen J. S., Chiu C. Y. Rapid Detection of 2019 Novel Coronavirus SARS-CoV-2 Using a CRISPR-based DETECTR Lateral Flow Assay. medRxiv., 2020, https://doi.org/10.1101/2020.03.06.20032334

20. Chen Y., Shi Y., Chen Y., Yang Z., Wu H., Zhou Z., Li J., Ping J., He L., Shen H., Chen Z., Wu J., Yu Y., Zhang Y., Chen H. Contamination-free visual detection of SARS-CoV-2 with CRISPR/Cas12a: A promising method in the point-ofcare detection. Biosens Bioelectron., 2020, vol. 169, pp. 112642.

21. Ding X., Yin K., Li Z., Lalla R. V., Ballesteros E., Sfeir M. M., Liu C. Ultrasensitive and visual detection of SARS-CoV-2 using all-in-one dual CRISPRCas12a assay. NatCommun., 2020, vol. 11, no. 1, pp. 4711.

22. Guo L., Sun X., Wang X., Liang C., Jiang H., Gao Q., Dai M., Qu B., Fang S., Mao Y., Chen Y., Feng G., Gu Q., Wang R. R., Zhou Q., Li W. SARS-CoV-2 detection with CRISPR diagnostics. Cell Discov., 2020, vol. 6, pp. 34.

23. Huang Z., Tian D., Liu Y., Lin Z., Lyon C. J., Lai W., Fusco D., Drouin A., Yin X., Hu T., Ning B. Ultra-sensitive and high-throughput CRISPR-p owered COVID19 diagnosis. Biosens Bioelectron., 2020, vol. 164, pp. 112316.

24. Ramachandran A., Huyke D. A., Sharma E., Sahoo M. K., Huang C., Banaei N., Pinsky B. A., Santiago J. G. Electric field-driven microfluidics for rapid CRISPRbased diagnostics and its application to detection of SARS-CoV-2. Proc Natl Acad Sci $U S$ A, 2020, vol. 117, no. 47, pp. 29518-29525.

25. Wang X., Zhong M., Liu Y., Ma P., Dang L., Meng Q., Wan W., Ma X., Liu J., Yang G., Yang Z., Huang X., Liu M. Rapid and sensitive detection of COVID-19 using CRISPR/Cas12a-based detection with naked eye readout, CRISPR/Cas12a-NER. Sci Bull (Beijing), 2020, vol. 65, no. 17, pp. 1436-1439.

26. Xiong D., Dai W., Gong J., Li G., Liu N., Wu W., Pan J., Chen C., Jiao Y., Deng H., Ye J., Zhang X., Huang H., Li Q., Xue L., Zhang X., Tang G. Rapid detection of SARS-CoV-2 with CRISPR-Cas12a. PLoS Biol., 2020, vol. 18, no. 12, pp. e3000978.

27. Curti L. A., Primost I., Valla S., Ibañez Alegre D., Olguin Perglione C., Repizo G. D., Lara J., Parcerisa I., Palacios A., Llases M. E., Rinflerch A., Barrios M., Pereyra Bonnet F., Gimenez C. A., Marcone D. N. Evaluation of a Lyophilized CRISPR-Cas12 Assay for a Sensitive, Specific, and Rapid Detection of SARS-CoV-2. Viruses, 2021, vol. 13, no.3. https://doi: 10.3390/v13030420.

28. Ding X., Yin K., Li Z., Sfeir M. M., Liu C. Sensitive quantitative detection of SARS-CoV-2 in clinical samples using digital warm-start CRISPR assay. Biosens Bioelectron., 2021, vol. 184, pp. 113218.

29. Garcia-Venzor A., Rueda-Zarazua B., Marquez-Garcia E., Maldonado V., Moncada-Morales A., Olivera H., Lopez I., Zuñiga J., Melendez-Zajgla J. SARS-CoV-2 Direct Detection Without RNA Isolation With Loop-Mediated Isothermal Amplification (LAMP) and CRISPR-Cas12. Front Med (Lausanne), 2021, vol. 8, pp. 627679. 
30. Huang D., Shi Z., Qian J., Bi K., Fang M., Xu Z. A CRISPR-Cas12a-derived biosensor enabling portable personal glucose meter readout for quantitative detection of SARS-CoV-2. Biotechnol Bioeng., 2021, vol. 118, no. 4, pp. 1587-1596.

31. Meng Q., Wang X., Wang Y., Dang L., Liu X., Ma X., Chi T., Wang X., Zhao Q., Yang G., Liu M., Huang X., Ma P. Detection of the SARS-CoV-2 D614G mutation using engineered Cas12a guide RNA. Biotechnol J., 2021, vol. 16, no. 6: e2100040.

32. Ning B., Yu T., Zhang S., Huang Z., Tian D., Lin Z., Niu A., Golden N., Hensley K., Threeton B., Lyon C. J., Yin X. M., Roy C. J., Saba N. S., Rappaport J., Wei Q., Hu T. Y. A smartphone-read ultrasensitive and quantitative saliva test for COVID-19. Sci Adv., 2021, vol. 7, no. 2.

33. Ooi K. H., Liu M. M., Tay J. W. D., Teo S. Y., Kaewsapsak P., Jin S., Lee C. K., Hou J., Maurer-Stroh S., Lin W., Yan B., Yan G., Gao Y. G., Tan M. H. An engineered CRISPR-Cas12a variant and DNA-RNA hybrid guides enable robust and rapid COVID-19 testing. Nat Commun., 2021, vol. 12, no. 1, pp. 1739.

34. Park J. S., Hsieh K., Chen L., Kaushik A., Trick A. Y., Wang T. H. Digital CRISPR/Cas-Assisted Assay for Rapid and Sensitive Detection of SARS-CoV-2. Adv Sci (Weinh), 2021, vol. 8, no. 5, pp. 2003564.

35. Rezaei M., Razavi Bazaz S., Morshedi Rad D., Shimoni O., Jin D., Rawlinson W., Ebrahimi Warkiani M. A Portable RT-LAMP/CRISPR Machine for Rapid COVID19 Screening. Biosensors (Basel), 2021, vol. 11, no. 10. https://doi.org/10.3390/bios11100369

36. Silva F. S. R., Erdogmus E., Shokr A., Kandula H., Thirumalaraju P., Kanakasabapathy M. K., Hardie J. M., Pacheco L. G. C., Li J. Z., Kuritzkes D. R., Shafiee H. SARS-CoV-2 RNA Detection by a Cellphone-Based Amplification-Free System with CRISPR/CAS-Dependent Enzymatic (CASCADE) Assay. Adv Mater Technol., 2021, https://doi.org/10.1002/admt.202100602

37. Wang R., Qian C., Pang Y., Li M., Yang Y., Ma H., Zhao M., Qian F., Yu H., Liu Z., Ni T., Zheng Y., Wang Y. opvCRISPR: One-pot visual RT-LAMP-CRISPR platform for SARS-cov-2 detection. Biosens Bioelectron., 2021, vol. 172, pp. 112766.

38. Zhu X., Wang X., Li S., Luo W., Zhang X., Wang C., Chen Q., Yu S., Tai J., Wang Y. Rapid, Ultrasensitive, and Highly Specific Diagnosis of COVID-19 by CRISPR-Based Detection. ACS Sens., 2021, vol. 6, no. 3, pp. 881-888.

39. Nguyen L. T., Smith B. M., Jain P. K. Enhancement of trans-cleavage activity of Cas12a with engineered crRNA enables amplified nucleic acid detection. Nat Commun., 2020, vol. 11, no. 1, pp. 4906.

40. Pang B., Xu J., Liu Y., Peng H., Feng W., Cao Y., Wu J., Xiao H., Pabbaraju K., Tipples G., Joyce M. A., Saffran H. A., Tyrrell D. L., Zhang H., Le X. C. Isothermal Amplification and Ambient Visualization in a Single Tube for the Detection of SARSCoV-2 Using Loop-Mediated Amplification and CRISPR Technology. Anal Chem., 2020, vol. 92, no.24, pp. 16204-16212.

41. Zhang Y., Chen M., Liu C., Chen J., Luo X., Xue Y., Liang Q., Zhou L., Tao Y., Li M., Wang D., Zhou J., Wang J. Sensitive and rapid on-site detection of SARSCoV-2 using a gold nanoparticle-based high-throughput platform coupled with CRISPR/Cas12-assisted RT-LAMP. Sens Actuators B Chem., 2021, vol. 345, pp. 130411.

42. Cao Y., Wu J., Pang B., Zhang H., Le X. C. CRISPR/Cas12a-mediated gold nanoparticle aggregation for colorimetric detection of SARS-CoV-2. Chem Commun (Camb)., 2021, vol. 57, no. 56, pp. 6871-6874.

43. Liang J., Teng P., Xiao W., He G., Song Q., Zhang Y., Peng B., Li G., Hu L., Cao D., Tang Y. Application of the amplification-free SERS-based CRISPR/Cas12a platform in the identification of SARS-CoV-2 from clinical samples. Nanobiotechnology, 2021, vol. 19, no. 1, pp. 273. 
44. Qian C., Wang R., Wu H., Zhang F., Wu J., Wang L. Uracil-Mediated New Photospacer-Adjacent Motif of Cas12a To Realize Visualized DNA Detection at the Single-Copy Level Free from Contamination. Anal Chem, 2019, vol. 91, no. 17, pp. 11362-11366.

45. Al-Shayeb B., Sachdeva R., Chen L. X., Ward F., Munk P., Devoto A., ... Clades of huge phages from across Earth's ecosystems. Nature, 2020, vol. 578, no.7795, pp. 425-431.

46. Pausch P., Al-Shayeb B., Bisom-Rapp E., Tsuchida C. A., Li Z., Cress B. F., Knott G. J., Jacobsen S. E., Banfield J. F., Doudna J. A. CRISPR-Cas $\Phi$ from huge phages is a hypercompact genome editor. Science, 2020, vol. 369, no.6501, pp. 333337.

47. Lee S., Kim T., Lee E., Lee C., Kim H., Rhee H., Park S. Y., Son H. J., Yu S., Park J. W., Choo E. J., Park S., Loeb M., Kim T. H. Clinical Course and Molecular Viral Shedding Among Asymptomatic and Symptomatic Patients With SARS-CoV-2 Infection in a Community Treatment Center in the Republic of Korea. JAMA Intern Med., 2020.10.1001/jamainternmed.2020.3862.

48. Udugama B., Kadhiresan P., Kozlowski H. N., Malekjahani A., Osborne M., Li V. Y. C., Chen H., Mubareka S., Gubbay J. B., Chan W. C. W. Diagnosing COVID19: The Disease and Tools for Detection. ACS Nano, 2020, vol. 14, no. 4, pp. 38223835.

49. Hussein H. A., Hassan R. Y. A., Chino M., Febbraio F. Point-of-Care Diagnostics of COVID-19: From Current Work to Future Perspectives. Sensors (Basel), 2020, vol. 20, no. 15 .

50. Joung J., Ladha A., Saito M., Segel M., Bruneau R., Huang M. W., Kim N. G., Yu X., Li J., Walker B. D., Greninger A. L., Jerome K. R., Gootenberg J. S., Abudayyeh O. O., Zhang F. Point-of-care testing for COVID-19 using SHERLOCK diagnostics // medRxiv. - 2020.10.1101/2020.05.04.20091231.

\title{
CRISPR/CAS12A НЕГIЗIНДЕГI КОВИД-19 ДИАГНОСТИКАСЫ
}

\author{
ҚабылбаеваА. ${ }^{1}$, ЖарылғасыноваК. ${ }^{1}$, АбиловаА. ${ }^{1}$, АманжоловаМ. ${ }^{2,3}$, \\ *Абельденов C. ${ }^{3}$ \\ ${ }^{1}$ Ғылымм және гуманитарлық дылымдар мектебі, Назарбаев Университеті, \\ Қабанбай батыр даңзвыльы, 53, Нұр-Сұлтан, Қазақсстан; \\ 2 Л.Н. Гумилев атындавы Еуразия ұлттық университеті, \\ Қазақстан, Нұр-Сұлтан, Қажымұқан көшесі, 13; \\ ${ }^{3}$ Ұлттық биотехнология ортальвы, \\ 010000, Қазақстан, Нұр-Сұлтан, Қоргалжын тас жоль 13/5. \\ *abeldenov@biocenter.kz
}

\section{АБСТРАКТ}

Нуклеин қышқылын анықтаудың жылдам және сенімді әдістеріне қол жеткізу көптеген салаларда өте маңызды болып табылады. Әр түрлі ауруларға байланысты генетикалық ақпаратқа негізделген патогендерді ерте және уақытылы анықтау ерте диагноз қоюға және емдеуге мүмкіндік береді.

COVID-19 пандемиясына қатысты жағдай қазіргі заманғы іргелі білімге негізделген диагностиканың жаңа әдістері үшін ферменттерді іздеудің шұғыл қажеттілігі бар екенін көрсетті. Қолданбалардың кең ауқымын қамтуға мүмкіндік беретін әдістер арзан болып келеді және арнайы жабдықтарды, білікті қызметкерлерді қажет етпейді және оларды 
жүзеге асыру оңай болып табылады. Осындай ферментердің бірі, жақында ашылған CRISPR/Cas жүйесінің эндонуклеазасы - Cas12a. Бұл шолуда біз Cas12a ферментінің сипаттамасын және оның COVID-19 диагнозында қолданылуын ұсынамыз. LAMP

Негізгі сөздер: CRISPR-Cas12a, COVID-19, диагностика, SARS-CoV-2, RT-RPA, RT-

\title{
ДИАГНОСТИКА COVID-19 на основе системы CRISPR/CAS12A
}

\author{
Кабылбаева А. ${ }^{1}$, Жарылгасынова К. ${ }^{1}$, Абилова А. ${ }^{1}$, Аманжолова М. ${ }^{2,3}$, \\ *Абельденов C. \\ ${ }^{1}$ Школа естественных и гуманитарных наук, Назарбаев Университет, \\ пр. Кабанбай батыра, 53, Нур-Султан, Казахстан. \\ ${ }^{2}$ Евразийский национальный университет имени Л.Н. Гумилева, \\ ул. Кажымукана, 13, Нур-Султан, Казахстан. \\ ${ }^{3}$ Национальный иентр биотехнологии, \\ Коргалжинское шоссе, 13/5, Нур-Султан, 010000, Казахстан. \\ *abeldenov@biocenter.kz
}

\begin{abstract}
АБСТРАКТ
Доступ к быстрым и надежным методам обнаружения нуклеиновых кислот имеет решающее значение во многих различных областях. Раннее выявление патогенов на основе их генетической информации, связанной с различными заболеваниями, делает возможными раннюю диагностику и лечение. Ситуация с пандемией COVID-19 показала, что именно сейчас существует острая необходимсть в поиске ферментов для новых методов диагностики, основанных на современных фундаментальных знаниях. Методы, позволяющие охватить более широкий круг приложений, будут дешевле, не потребуют специализированных помещений, квалифицированного персонала и просты в реализации. Одним из таких методов является система, основанная на недавно обнаруженной эндонуклеазе системы CRISPR/Cas - Cas12a. B этом обзоре мы приводим описание фермента Cas12a и его использование в диагностике COVID-19. LAMP.

Ключевые слова: CRISPR-Cas12a, COVID-19, диагностика, SARS-CoV-2, RT-RPA, RT-
\end{abstract}

